\title{
I SING THE BODY DYSTOPIC: UTOPIA AND POSTHUMAN CORPOREALITY IN P.D. JAMES'S THE CHILDREN OF MEN
}

Eduardo Marks de Marques

Universidade Federal de Pelotas

\begin{abstract}
The resurgence of novels dealing with dystopian cosmogonies since the 1990s may reveal a new trend in Utopian Studies. If classical dystopia was defined by the imposition of collective political and social structures upon the individual and out of which there was no escape (as constructed, mainly, by Aldous Huxley's Brave New World and George Orwell's Nineteen EightyFour), these contemporary dystopian novels critically construct posthuman societies where the focus is on the development of the dystopian body, which questions and reinvents the very definitions of humanity. This article aims at examining the effects of posthuman critique upon the construction of the dystopian body in P.D. James's novel The Children of Men.
\end{abstract}

Keywords: contemporary dystopias; dystopian bodies; posthumanism; utopian studies. 
The studies of Utopia, either as political and social project, or as a literary and cultural genre, necessarily encounter a complex difficulty with the rise of a form of literature that deviates from the radical hope of eutopia ${ }^{1}$ towards the militant pessimism of its polar opposite, that of dystopia (Moylan 157). Ideologically speaking, if the classic form of utopian literature is a product of the Renaissance, its contemporary form has its origins in the Enlightnenment, with its scientific inclination. However, the rise of communist states in the twentieth century had a deep impact in utopian thought. Not only the fact that all communist nations were born under or soon became totalitarian regimes, but (and, perhaps, most importantly) a general distrust in the state of technological society in the wake to (and after) the Great War changed not only utopian philosophy but utopian literature as well. The tight grip of the state on individual subjectivities, combined with widespread propaganda and the dictator's personal charisma, marketed as the only possible form to maintain the revolutionary impetus alive (Arendt 306-07), and also the critique of the role of history are arguably in the core of the second dystopian $\operatorname{turn}^{2}$ (Claeys 111-12): the dream of the ideal place, brought about by radical changes in the base-superstructure relationship, becomes the nightmare of an undesired reality, at least for the majority of the population.

Gregory Claeys, in his essay "The Origins of Dystopia: Wells, Huxley and Orwell", discusses the main works that set the tone for the understanding of utopia as dystopia in the twentieth century. What H.G. Wells, Aldous Huxley, and George Orwell share is not, as may be seen superficially, a critique of one or another form of socio-political organization but, rather, a critique of (and anxiety upon) the modern impossibility of achieving a necessary balance between an economic system which may level out or even eradicate social differences and 
a political system which may control such an achievement and, still, maintain sociocultural individualities untouched at the same time as this achievement is constructed as part of historical materialism.

In two of the most important novels of such a trend, Huxley's Brave New World (1932) and Orwell's Nineteen Eighty-Four (1949), despite the obvious and useless man-versus-system struggle (showing not the failure of totalitarian regimes to control all individuals but, rather, the far stronger message that resistance is futile), one of the main dystopian elements is the detachment from the historical continuum (by creating a new continuum, in Huxley; by constantly rewriting the continuum, in Orwell). If, on the one hand, classic eutopias exist regardless of history, the advent of socialist utopianism-and its Marxist critique-bring history to the equation as a vital tool in the maintenance of the system and, thus, of the revolutionary efforts behind it (technological revolution in Huxley; political in Orwell).

When one refers to utopianism, both as a political project and as the tools needed to implement such a project-of which literature is but a very important one-one ultimately draws a line. On one side, one finds those classic and undoubtedly eutopian narratives (Plato's Republic; Thomas More's Utopia) where one can identify the desire and impulse for the creation of a better society didactically (in Plato's case) or by comparison with a perfect yet unreal community (in More's case). On the other side, are those twentieth century narratives which have come to being known as dystopian, primarily represented by Aldous Huxley's Brave New World and George Orwell's Nineteen Eighty-Four, where the fears of an undesirable society are presented, either by the strong grasp of Capitalism and scientificism (in Huxley) or by a deviation of the original Socialist desire for utopia (in Orwell). 
Such a distinction, though, is merely didactic and problematic. As Lyman Tower Sargent, in his Utopianism-A very brief introduction (2010), when trying to define the genre, states,

[a]ll utopias ask questions. They ask whether or not the way we live could be improved and answer that it could. Most utopias compare life in the present and life in the utopia and point out what is wrong with the way we now live, thus suggesting what needs to be done in order to improve things. (5)

If it is agreed that the questions utopia asks may refer to expose both the flaws in contemporary society and possible improvements to it in the future, the line that divides utopia and dystopia becomes virtually non-existent. A superficial analysis of Huxley's and Orwell's novels, for instance, indicates that the societies of the Brave New World and of Oceania, respectively, have not been thought out to be dystopias but eutopias-and, in fact, for part and parcel of the population of those societies, they indeed are eutopias. Raffaella Baccolini and Tom Moylan aptly refer to dystopias as "the dark side of Utopia" (1), making it not only connected directly to but indivisible from eutopia.

Perhaps it is possible to affirm that the postmodern reinvention of Utopia is as dystopia though not in the old Manichean sense. Dunja M. Mohr, in her article "Transgressive Utopian Dystopias: The Postmodern Reappearance of Utopia in the Disguise of Dystopia", discusses the impact of the thesis of the end of history on the reinvention of the classic Utopian model of the nineteenth and twentieth centuries. Francis Fukuyama explains the apparent end of Utopia as a necessary consequence of the victory of liberal democracies over their alternative political projects: 
We who live in stable, long-standing liberal democracies face an unusual situation. In our grandparents' time, many reasonable people could foresee a radiant socialist future in which private property and capitalism had been abolished, and in which politics itself was somehow overcome. Today, by contrast, we have trouble imagining a world that is radically better than our own, or a future that is not essentially democratic and capitalist. Within that framework, of course, many things could be improved: we could house the homeless, guarantee opportunity for minorities and women, improve competitiveness, and create new jobs. We can also imagine future worlds that are significantly worse than what we know now, in which national, racial, or religious intolerance makes a comeback, or in which we are overwhelmed by war or environmental collapse. But we cannot picture to ourselves a world that is essentially different from the present one, and at the same time better. Other, less reflective ages also thought of themselves as the best, but we arrive at this conclusion exhausted, as it were, from the pursuit of alternatives we felt had to be better than liberal democracy. (42)

Fukuyama's thesis, that Western societies have already reached their social and economic developmental pinnacle, leads us directly to the impossibility of Utopia since it is in itself the very realisation of the utopian project and, thus, whatever might be imagined from within Utopia cannot be eutopic in nature, but dystopic. This may explain, in part, the resurgence of dystopian literature (not necessarily connected to its seemingly Siamese genre, science fiction) since the early 1990s in Anglophone countries.

Although Mohr's construction of the notion of transgressive utopian dystopias stems from the rise of feminist literary utopias in between the 1960s and the 1980s, she explains that

[t]he thematic concerns of these 'dystopias' involve transgressions of subject/object, male/female, human/animal 
and human/alien or human/non-human, master/slave, nature/ nurture, nature/culture, mind/body, sanity/madness, self/other, literacy/orality, codes/ stereotypes, the relation between myth/ history with regard to the (im)pos-sibility of a representation of reality and truth(s). The texts reject "a determinist, teleological link between past, present and future" (Sargisson 1996, 225) and offer multiple or heterogeneous alternative views rather than the possession of one reality and $a$ future. (12)

The $\mathrm{u} /$ dys-topian dynamics is, thus, oriented towards a new, postmodern understanding of Utopia as a project that rejects the universalities of blueprint Utopianism but acknowledges its position in the Utopian continuum. A similar understanding of the connections between Utopia and dystopia in postmodernism can be found in Margaret Atwood's critical study, In Other Worlds: SF and the Human Imagination (2011), in which she discusses what she refers to as "ustopia" (66), a genre which blends, even in its very name, the notions of utopia and dystopia.

Many of the binaries presented by Mohr as those that are transgressed by the transgressive utopian dystopias center in the understanding of the body and, in this regard, one may find in Fredric Jameson a possible way of introducing the dystopian body to the argument. Jameson has always been an avid scientific fiction reader and most if not all theorists devoted to the genre nowadays see in the Marxist critic one of the main responsible academics for giving this genre a truly literary status. In the introduction to his collection of essays on utopia and science fiction, Archaeologies of the Future: The Desire Called Utopia and Other Science Fictions (2005), Jameson traces the connections between utopia and politicsespecially in the twentieth century-as that mode of thought was once thought to answer the questions of any possible alternative to the capitalist mode of organisation. If any anti-capitalist mode of thought 
required an understanding of the possibility of a better life (meaning, obviously, a general sense of disenchantment with whatever is meant to be "real life"), the practical constructions of such utopias have proven to be actual dystopias, in "a will to uniformity and the ideal purity of a perfect system that always had to be imposed by force on its imperfect and reluctant subjects" (xi), thus connecting the communist experiments with totalitarianism, a point also made by Fatima Vieira, to whom any flaws in the utopian project are, actually, flaws in the human spirit (22). Thus, one can easily see the complex connections between utopia and dystopia.

Reading extensively through modern philosophy, particularly the ideas of the German Marxist thinker Ernst Bloch about Utopia, Jameson identifies two major axes in utopianism, considering More's work as its actual starting point: namely those of the utopian program and utopian impulse (Jameson 3-4). Reducing these axes to their simplest drives, the utopian program is present-oriented, and connected-albeit tangentially-to what most utopian thinkers refer to as blueprint (usually connected to pre-twentieth century literary utopias, although the idea of a readymade plan for a working utopian society has since been denounced by Marx and his successors). Bloch's (and Jameson's) utopian program should be seen, thus, as a work in progress, one which would involve, as shown in the diagram below, a rearrangement of the urban locus around the ideas of a revolution sustained by, among other things, praxis and literature.

The utopian impulse, on the other hand, is present-to-futureoriented and is concerned in crystallizing the utopia not only by maintaining the revolutionary ideals presented in the program but, mainly, preventing the appearance of counterrevolutionary ideas which might jeopardize the utopia. Interestingly, in contrast to "the city itself as a fundamental form of the Utopian image (along with 
the shape of the village as it reflects the cosmos)", Jameson points out the role of "the individual building as a space of Utopian investment, that monumental part which cannot be the whole and yet attempts to express it" (4). However, the most important element in the analysis of the utopian impulse is undoubtedly the hermeneutical one, involving corporeality, chronology, and collectivity, being the first the most important.

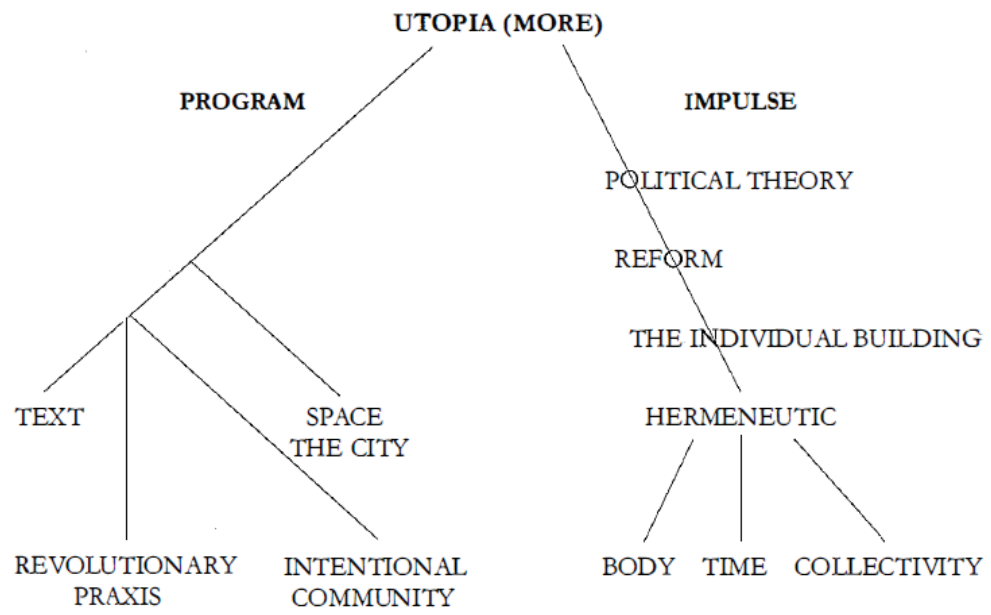

Fig. 1.-Jameson's diagram of utopian program and impulse [4]

The material body becomes central in understanding contemporary utopias. Jameson states that

$[\mathrm{m}]$ aterialism is already omnipresent in an attention to the body which seeks to correct any idealism or spiritualism lingering in this system. Utopian corporeality is however also a haunting, which invests even the most subordinate and shamefaced products of everyday life, such as aspirins, laxatives and 
deodorants, organ transplants and plastic surgery, all harboring muted promises of a transfigured body. (6)

Modern utopias (not unlike their contemporary, twentieth and twentieth-first century counterparts) have, then, drawn heavily on scientific developments in order to guarantee the utopian promise of the mutability (towards perfection) of the utopian body, a trend perhaps inaugurated by Mary Shelley's Frankenstein; or, The Modern Prometheus (1818), establishing not only the known approximation between utopian fiction and the genre Shelley allegedly initiated of science fiction (Freedman 62), but also that between Utopia and the post-human body.

The third dystopian turn in literature, thus, is one where the centre of Utopia is not in a centralized form of social, political and/or cultural control upon individuals but, rather, in the dystopian, posthuman body, which is the result of postmodern life and technological advances. Posthumanist thought is complex and multilayered and, as such, has to be limited to the scope of the argument at hand. Cary Wolfe introduces the complexity of posthumanism by stating that

it comes both before and after humanism: before in the sense that it names the embodiment and embeddedness of the human being in not just its biological but also its technological world, the prosthetic coevolution of the human animal with the technicity of tools and external archival mechanisms (such as language and culture) of which Bernard Stiegler probably remains our most compelling and ambitious theorist-and all of which comes before that historically specific thing called "the human" that Foucault's archaeology excavates. But it comes after in the sense that posthumanism names a historical moment in which the decentering of the human by its imbrication in technical, medical, informatic, and economic networks is 
increasingly impossible to ignore, a historical development that points toward the necessity of new theoretical paradigms (but also thrusts them on us), a new mode of thought that comes after the cultural repressions and fantasies, the philosophical protocols and evasions, of humanism as a historically specific phenomenon. (xv-xvi)

Such a turn is, of course, connected to the rise of feminist utopias but the dismantlement of a well-defined concept of what it means to be human is, in essence, the ultimate result of liberal democracies and, also, of Capitalism. Donna J. Haraway's "A Cyborg Manifesto" is probably the first attempt to rethink feminism in the wake of late Capitalism by discussing the merge between the organic-once the realm of the sacred and indivisible-and the technological, which derives from the everlasting need not just to prolong life but to surrender oneself to desire. The relationship between humans (whatever the word may mean nowadays) and machines is driven by a constant reinvention of the human. The cyborg, this entity part organic, part inorganic and technological, is the ultimate capitalist commodity since desire never ceases to exist. Wolfe discusses posthumanism and transhumanism as follows:

Arguably the best-known inheritor of the "cyborg" strand of posthumanism is what is now being called "transhumanism"-a movement that is dedicated, as the journalist and writer Joel Garreau puts it, to "the enhancement of human intellectual, physical, and emotional capabilities, the elimination of disease and unnecessary suffering, and the dramatic extension of life span. What this network has in common," Garreau continues, "is a belief in the engineered evolution of 'post-humans', defined as beings 'whose basic capacities so radically exceed those of present humans as to no longer be unambiguously human by our current standards.' "Transhuman," he concludes, "is 
their description of those who are in the process of becoming posthuman." As one of the central figures associated with transhumanism, the Oxford philosopher Nick Bostrom, makes clear, this sense of posthumanism derives directly from ideals of human perfectibility, rationality, and agency inherited from Renaissance humanism and the Enlightenment. (And in this, it has little in common with Haraway's playful, ironic, and ambivalent sensibility in "A Cyborg Manifesto," which is suspicious - to put it mildly-of the capacity of reason to steer, much less optimize, what it hath wrought.) (xiii)

The ultimate capitalist victory is, thus, the construction and maintenance of posthuman bodies driven by the desire to never grow old and/or perish and, in this, sex and gender differences are irrelevant as desire exists beyond these characteristics (Turner 32). The posthuman body, therefore, does not allow any features that can be seen as imperfections. Whatever characteristics either culturally perceived as flaws or actual organic defects one has can only be seen as dehumanising and, as such, as something that has to be corrected and/or perfected by technological interference. The "original" human body is essentially inhuman and it has to become (post)human by embracing late Capitalism and its technologies.

This is the trend which can be found in many Anglophone novels deemed utopic, dystopic or speculative fiction since the late 1990s, and it can be found in P.D. James's dystopian novel, The Children of Men (1992). Set within the entire year of 2021 in and around Oxford, the novel presents a dystopian Britain in a world where male humans have lost their fertility for over twenty-five years. The novel, part epistolary, opens with the protagonist, Theodore (Theo) Faron, an historian, writing on his diary about the death of the world's youngest person, Argentine Joseph Ricardo ${ }^{3}$, killed in a pub brawl (3). Theo sees himself as the keeper of historical knowledge 
which will soon become meaningless and this sets him in a mood of depressive despair.

Through his words in the epistolary chapters and his actions elsewhere, this dystopian space is slowly constructed. The government is no longer centred in the monarch but in the political figure of Theo's cousin, Xan Lypiatt, the self-appointed Warden of Britain-an interesting title, as it refers to the carer of a prison block, for instance, and whose power lies exactly on the restraint of individual, bodily actions that may jeopardize the collective project.

An important group in this society is that of the Omegas, members of the generation born in 1995, the last year with recorded births. Omegas are granted a series of social privileges and, interestingly, they seem to display their given social superiority physically:

The female Omegas have a different beauty, remote, listless, without animation or energy. They have their distinctive style which other women never copy. They wear their hair long and loose, their foreheads bound with braid or ribbon, plain or plaited. It is a style which suits only the classically beautiful face, with its high forehead and large, widely spaced eyes. Like their male counterparts, they seem incapable of human sympathy. Men and women, the Omegas are a race apart, indulged, propitiated, feared, regarded with a half-superstitious awe. In some countries, so we are told, they are ritually sacrificed in fertility rites resurrected after centuries of superficial civilization. I occasionally wonder what we in Europe will do if news reaches us that these burnt offerings have been accepted by the ancient gods and a live child has been born. (James 10-11)

It is interesting to see the corporeal contradiction surrounding the Omegas. They are seen as a quasi-perfect group-and, thus, should somehow be the ultimate representatives of humanity in all its possible meanings. Instead, the Omegas have abandoned 
their humanity to become empty corporeal vessels, incapable of maintaining a sense of community (and, thus, of humanity) with other people who are not Omegas. The Omega body is not only physically but, most importantly, psychologically and socially sterile.

Ironically, in a world where there have been no births for over twenty years, the government encourages the elderly to commit assisted suicide in ceremonies called Quietus. Such ceremonies, of which Theo recalls "one picture ....: white-clad elderly being wheeled or helped on to the low barge-like ship, the high, reedy singing voices, the boat slowly pulling away into the twilight, a seductively peaceful scene, cunningly shot and lit" (47), indicate yet another deeper paradoxical irony of this dystopia. The aging body needs to be eliminated not because it needs to give room to a young one but, simply, because this dystopia cannot tolerate unable and disabled bodies. The cult to the socially inept though young Omegas makes the intolerance to old age even more ironic: it refers to the necessity to create a new sense of history and historical materialism detached from the continuum that is dying with the loss of fertility. Originally sterile bodies are still more central to the maintenance of social relations in this dystopia than those bodies whose age have rendered sterile.

The Quietus is, however, nothing like the placid image Theo remembers seeing on television. The man decides to witness the ritual, which The Five Fishes, a small group of revolutionaries whose purpose is to overthrow the totalitarian government of Britain, accuse of being nothing but murder. Theo finds that the elderly being carried to the boats out of which they were to be taken offshore looked heavily sedated (73-74) and nothing like the advertised image of willing suicides sold by the government. In fact, what the man sees is really murder: 
Suddenly, there was a commotion. One of the women being helped on to the nearer boat gave a cry and began a violent thrashing of her arms. The nurse with her was taken by surprise and, before she could move, the woman had leapt from the jetty into the water and was struggling ashore. Instinctively Theo cast off his heavy coat and ran towards her... . She was about twenty yards from him now and he could see her plainly, the wild white hair, the nightdress sticking to her body, the swinging, pendulous breasts, the arms with their weals of crêpy skin. A crashing wave tore the nightdress from her shoulder and he saw the breast swaying obscenely like a giant jellyfish. She was still screaming, a high, piercing whistle like a tortured animal. ...

And then it happened. His outstretched hands were about to grasp her wrists when one of the soldiers leapt into the water from the jetty and, with the butt of his pistol, struck her viciously on the side of the head. She fell forward into the sea, arms whirling. There was a brief stain of red before the next wave came, engulfed her, lifted her, receded and left her spreadeagled in the foam. She tried to rise but again he struck. ... (74-75)

Such rituals of elderly genocide are carried out in the sea not only as a way to destroy the aging bodies but to leave no trace of them inland and, thus, erasing them from the new project of historical continuum. These bodies, when killed, are deprived of their religious right of a burial, which symbolizes the return to earth and the entry to eternal life. Instead, they are drowned-killed by the very element which symbolizes life. Dying surrounded by water because of nothing except being old ironically represents the merge between the beginning and the end (the Alpha and the Omega, namely the two parts of The Children of Men). The aging body, be that of British citizens, be that of the Sojourners-foreigners allowed into Britain 
to work in hard labour or menial jobs and who face compulsory deportation at the age of sixty-has no room or function whatsoever.

In this context, Theo sees himself involved The Five Fishes. He only does so because of his feelings for Julian, a woman who reaches Theo for his help to get a message to Xan. Julian is described as follows:

Her hair, dark and luscious, a rich brown with flecks of gold, was brushed back and disciplined into a short, thick pleat. A fringe fell over a high, freckled forehead. She was light-skinned for someone so dark-haired, a honey-coloured woman, longnecked with high cheekbones, wide-set eyes whose colour [Theo] couldn't determine under strong straight brows, a long narrow nose, slightly humped, and a wide, beautifully shaped mouth. It was a pre-Raphaelite face. Rossetti would have liked to paint her.... She was gloveless and he could see that her left hand was deformed. The middle and forefinger were fused into a nail-less stump and the back of her hand was grossly swollen. She held it cradled in her right as if comforting or supporting it. There was no effort to hide it. She might even have been proclaiming her deformity to a world which had become increasingly intolerant of physical defects. But at least, he thought, she had one compensation. No one who was in any way physically deformed, or mentally or physically unhealthy, was on the list of women from whom the new race would be bred if ever a fertile male was discovered. She was, at least, saved from the six-monthly, timeconsuming, humiliating re-examinations to which all healthy females under forty-five were subjected. (39)

Julian's body is only allowed to exist in its actual state in that society because it is assumed to be sterile. Humanity, in James's dystopia, is related not only to the hope of procreation but, also to an ablebodied existence. Superficially, at least, Julian fulfils neither requisite.

And it is exactly in this aspect that lies the central tension of the novel. Months after their first contact, Julian calls for Theo again to 
disclose that she is pregnant. Julian's pregnancy is seen with extreme caution by The Five Fishes because they do not wish to have the Warden use the baby for political reasons, namely that in which Britain comes out as the saviour of a dying world. However, the main issue here is related to Julian's sub-human status in a posthuman world. If her body is deemed invisible and useless in that society, then it should have no right to bear a new life. Also, like in most classical dystopias of the twentieth century and as mentioned elsewhere in this article, Julian's pregnancy may also be seen as the "individual versus the system" trend, where the bodily limits and imperfections of the element of defiance are setbacks (as, for instance, Winston Smith's festering varicose ulcer in Nineteen Eigthy-Four or John the Savage's decadent mother in Brave New World). Here, however, such a defiant act cannot be seen as a planned act and it does have an impact upon the system.

Her pregnancy sets Theo and the Fishes-Rolf, Julian's husband; Luke, a Catholic priest; Miriam, a former midwife-on the run in the English countryside after the government captures Gascoigne, another member of their organisation. One night, they are attacked by a group of Omegas, who are reverted into a strange primitivism:

And in that second the Omegas were upon them. Horribly, they came at first unheard, in total silence. At each car window the painted faces stared in, lit by the flames of torches... The engine roared into life, the car shot back. They crashed to a stop with a violence which threw them forward.... And now the faces were at the windows again. He stared into two expressionless eyes, gleaming, white-rimmed, in a mask of blue, red and yellow swirls. Above the painted forehead the hair was dragged back into a top-knot. In one hand the Omega held a flaming torch, in the other a club, like a policeman's truncheon, decorated with thin pigtails of hair. Theo remembered with horror when being 
told that when the Painted Faces killed they cut off the hair of the victim and braided it into a trophy, a rumour he had only half believed, part of the folklore of terror. . . (179)

The Omegas, then, start doing a sort of tribal, ritual dance round the car while choosing a single sacrificial victim (180). Theo's plan is to have them join the dance and run away at the first possible occasion (181). Never does the man think of reasoning with the Omegas, which further exposes the complexities in the human-inhumanposthuman equation. The Omegas, seen as the pinnacle in aesthetic development and whose bodies carry not only an inimitable style, but also an ennui which places them in the limbo between human and posthuman, revert to barbarism, the absence of civilization, thus choosing to behave and be seen as non-human.

The end of the novel sees the birth of Julian's baby, a boy (229)who may symbolize either the beginning of a new era or, simply, the maintenance of the world's decay as infertility is a masculine problem-and the subsequent killing, by Theo, of the Warden of England, who planned to marry Julian and present the baby to the world as his own (and, of course, to symbolize British superiority over this dying world). The power is, then, shifted to the Council of England, headed by a woman, who takes both mother and baby to hospital for proper care. In the end, there is no sense of hope that humanity will be restored or, even, that the Omega sense of post/ inhumanity will cease to be praised. The final act in the novel is the baby's improvised christening as a Catholic, which might indicate the path society-should the baby really be the bearer of a new beginningwill hold. However, at the end of the novel, there is actually no sense of closure or change whatsoever, and this, in essence, mimics the Omega attitudes towards the world. 
The lack of closure in the end of The Children of Men is symptomatic of the tension between utopia and the posthuman/ transhuman body. If such bodies are in the center of the utopian desire, are they to create and maintain eutopias or to create and maintain dystopias, considering the didactic though improbable argument that dystopias are created as such? Interestingly, however, is the fact that, in the novel, the hope for the maintenance of humankind is a "pretranshuman" body: a full human, born naturally out of a seemingly infertile body. Technology, the key to create transhumanism, has failed, since it did not detect Julian's or the priest's fertility mainly because it was the role of technology to rule out the possibility of "imperfect" bodies be used as fertile vessels. The irony in the bleak end of the novel indicates that this is the future of humanity: to embrace the possibility of origin by what may be seen as imperfect and, essentially, human.

\section{Notes}

1. The term "eutopia" is used, in Studies of critical utopia, to establish positive utopias rather than negative ones-dystopias-since the term "utopia" may mean both, since what it really refers to is the impulse and desire to create better societies.

2. The first dystopian turn is that which followed the French Revolution and carries, according to Claeys, "[s]atires upon Enlightenment conceptions of a life lived according to principles of reason" (110) and exposes, primarily, the flaws in human reason as a principle of political organization.

3. It is ironic, at least, that the last person born in James's dystopia is Argentinian, which may echo the long-lasting conflict between that country and Britain over the Falklands. 


\section{References}

\section{a) Primary Source}

James, P. D. The Children of Men. New York: Vintage Books, 1992. Print.

\section{b) Secondary Sources}

Arendt, Hannah. The Origins of Totalitarianism. New Edition. San Diego: Harvest Books, 1976. Print.

Atwood, Margaret. In Other Worlds: SF and the Human Imagination. London: Virago Press, 2011. Print.

Baccolini, Raffaella and Moylan, Tom. "Introduction: Dystopia and Histories". Baccolini, Raffaella and Moylan, Tom. (Eds). Dark Horizons: Science Fiction and the Dystopian Imagination. New York: Routledge, 2003. 1-12. Print.

Claeys, Gregory. "The Origins of Dystopia: Wells, Huxley and Orwell”. Claeys, Gregory (Ed.). The Cambridge Companion to Utopian Literature. Cambridge: U of Cambridge P, 2010. 107-31. Print.

Freedman, Carl. Critical Theory and Science Fiction. Middletown: Wesleyan Press, 2000. Print.

Fukuyama, Francis. The End of History and the Last Man. New York: Free Press, 1992.

Haraway, Donna J. “A Cyborg Manifesto: Science, Technology, and SocialistFeminism in the Late Twentieth Century". Haraway, Donna J. Simians, Cyborgs, and Women: The Reinvention of Nature. New York: Routledge, 1991. 149-81. Print.

Jameson, Fredric. Archaeologies of the Future: The Desire Called Utopia and Other Science Fictions. London: Verso, 2005. Print.

Mohr, Dunja M. “Transgressive Utopian Dystopias: The Postmodern Reappearance of Utopia in the Disguise of Dystopia”. Zeitschrift für Anglistik und Amerikanistik (ZAA) 55.1 (2007): 5-24. Print.

Moylan, Tom. Scraps of the Untainted Sky: Science Fiction, Utopia, Dystopia. Boulder: Westview Press, 2000. Print. 
Tower Sargent, Lyman. Utopianism-A very brief introduction. Oxford: Oxford UP, 2010. Print.

Turner, Bryan S. The Body \& Society: Explorations in Social Theory. $3^{\text {rd }}$ Ed. Los Angeles: Sage, 2008. Print.

Vieira, Fatima. "The Concept of Utopia”. Claeys, Gregory (Ed.). The Cambridge Companion to Utopian Literature. Cambridge: $\mathrm{U}$ of Cambridge P, 2010. 3-27. Print.

Wolfe, Cary. What is Posthumanism? Minneapolis: U of Minnesota P, 2010. Print.

(Received in 01/06/2013. Approved in 31/09/2013) 